\title{
Violence and communication
}

\author{
Jozef Novak-Marcincin ${ }^{1}$, Daniela Gîfu ${ }^{2, *}$, Mirela Teodorescu ${ }^{3}$ \\ ${ }^{1}$ Technical University of Kosice, Kosice, Slovakia \\ 2“Alexandru Ioan Cuza” University of Iaşi, Bd. Carol I no. 11, Iaşi, 700506, Romania \\ 3 University of Craiova, 13 A. I. Cuza Street, Craiova, 200585, Romania \\ *E-mail address: danigifu@yahoo.com
}

\begin{abstract}
The study sets to catagrafy the "violence" phenomenon in actual human society. The diversity of violence types, the education segments, the age segments who aggress and who are aggressed, get more and more extended. The social context is crucial for both the performance and understanding of violence. The term 'senseless violence' is often heard in cases where a serious violent incident was apparently unprovoked or has emerged from "insignificant" insults or altercation. The notion of "senseless" violence is, by implication, contrasted to some other 'reasonable' kind, or perhaps suggests that what we find repugnant needs to be placed beyond the bound of sense. Most people probably have a wordless conception of what is a reasonable response to offence or provocation, for example, a fatal shooting following an altercation over a parking place appears inexplicable and senseless. Still many acts of extreme violence occur in response to apparently minor incidents and violence nearly always has "sense", that is, social meaning, to both perpetrators and victims. The targets of violence are rarely chosen randomly and the victims and perpetrators are frequently already known to each other. In some cases the attribution "senseless" refers to an assumed mental illness or other pathology that might account for otherwise incomprehensible behavior. Human society registered besides direct violence: war, murder, rape, assault, verbal attacks, that is the kind that we physically perceive, another two invisible forms and can't be eliminated without eliminating them, cultural violence and structural violence. Direct violence has its roots in cultural and structural violence; then it feeds back and strengthens them. All three forms interact as a triad. Direct violence reinforces structural and cultural violence. We are trapped in a vicious cycle that is now threatening to destroy life on earth.
\end{abstract}

Keywords: violence; communication; direct violence; structural violence; cultural violence

\section{INTRODUCTION}

The World Health Organization defines violence as "the intentional use of physical force or power, threatened or actual, against oneself, another person, or against a group or community, which either results in or has a high likelihood of resulting in injury, death, psychological harm, maldevelopment, or deprivation", but acknowledges that the inclusion of the "the use of power" in its definition expands on the conventional meaning of the word (Krug et al., 2002). Making some statistics, globally, violence takes the lives of more than 1.6 million people annually. Just over $50 \%$ due to suicide, some $35 \%$ due to homicide, and just over 12 $\%$ as a direct result of war or some other form of conflict. Statistics show that gunfire kills ten 
children a day in the United States. Corlin, past president of the American Medical Association said: "The United States leads the world - in the rate at which its children die from firearms". He concluded, "Gun violence is a threat to the public health of our country". For each single death due to violence, there are dozens of hospitalizations, hundreds of emergency department visits, and thousands of doctors' appointments. Furthermore, violence often has lifelong consequences for victims' physical and mental health and social functioning and can slow economic and social development.

\section{VIOLENCE CAUSE}

There is a huge concern about violence in the world today. What causes violence? Why do some children hit or bite? And how do sweet little babies turn into gun-carrying gang members, murderers, and terrorists?

Basically, there are two conditions that produce violent tendencies in human beings. One condition is that the person has been hurt. A child who is spanked, hit, beaten, or threatened with violence will have a tendency to become violent himself. Sexual abuse and emotional neglect, the accumulation of minor hurts (stress), the anxieties, disappointments, and frustrations of childhood lead to a violent behavior as well. The second basic condition is less well understood. The person has not been allowed to release the emotions resulting from the hurts. The unresolved and unexpressed feelings about what he has experienced are reasons of violence behavior. Being the victim of violence and other distressing experiences breeds violence in the child only when the emotions are blocked and repressed. When this situation occurs, violence toward self or others is almost an inevitable outcome. Violence is a distorted expression of the person's rage or terror in an environment, am emotional discharge, a psychological breakdown where it is not safe to reveal or release strong feelings. Adding to these conditions is the fact that violence is tolerated and glorified in most industrialized countries, and is culturally linked to appropriate male behavior. Children are exposed to violent male sports, and to television programs, films, and electronic games with mostly violent male protagonists. Little boys are given toy soldiers, guns, and other war paraphernalia with which to play. Story books and school text books often glorify war, a predominantly masculine activity, and describe great male conquerors as heroes. Many parents are pleased when their sons fight back in self-defense with playground bullies, and adults worry about boys who refuse to fight. All of these, combined with the fact that boys are expected to be tough and not cry, it is not surprising that men commit more violent crimes than women.

\section{PSYCHOLOGICAL EXPLANATION OF VIOLENCE}

Sigmund Freud (1915) pointed out that civilization is only made possible by individual renouncements, including the renouncement of violence. Violent individuals, nonetheless, often experience no guilt about a violent act nor do they empathies with their victim. The psychoanalytic comprehension of both the roots of violence and the ways in which people connect with one another is a critical factor in understanding the violent behavior and furnish a solution to this nationwide problem. Sigmund Freud also stated that humans instinctually are aggressive and seek egoistic self-satisfaction. Our culture, however, has been designed to put prohibitions and curbs upon our human tendencies toward unchecked aggression and egoistic self-satisfaction. From these prohibitions and curbs come a sense of guilt-conscious and 
unconscious-that has become the hallmark of civilized humanity. The major work in which he analyzed the problem of violence was Civilization and its Discontents (1930) in which he discussed the irremediable antagonism between the demands of instinct and the restrictions of civilization. In Thoughts on War and Death (1915), written at the beginning of the horrors of World War I, he wrote about the general, including his own, disillusionment brought about by countries acting immorally and by individuals acting brutally.

Psychoanalysis shows that human nature is composed of primitive impulses, including selfish and cruel impulses. The primitive impulses undergo a lengthy process of modification during one's development, they are inhibited, redirected to different aims. Civilization is attained through renouncing or controlling these impulses. Similarly, civilized societies expect and demand that newcomers to their society also control these impulses and to be able to relate to one another. In social interactions, it is natural that people have mixed feelings toward people they must interact with, and which results in a conflict between love and aggression. Some people have a great deal of guilt (even an unconscious sense of guilt) and may unconsciously direct great harm towards himself. This leads to a great deal of self-punishment. Since this can be a common problem, many people falsely think that the solution to life's problems is to eliminate guilt and to lead "guilt-free" lives. However, it is impossible and unwise to totally eliminate guilt. Human life in a community is only possible as a result of people coming together and agreeing that no one individual can exert power over another and where individuals agree to restrict their own personal inner wishes in favor of the communal needs. In other words, people have to develop the two Freudian tenets of human nature and society: guilt and empathy for fellow humans. One of the major problems for humanity is reaching a balance between the desires of one individual and the claims of the social group. Debate continues on whether this problem can be resolved or whether it is irreconcilable.

\section{DESCRIPTION AND CLASSIFICATION OF VIOLENCE}

\section{1. Physical Violence}

Physical violence occurs when someone uses a part of their body or an object to control a person's actions. Physical violence includes, but is not limited to:

Using physical force which results in pain, discomfort or injury; Hitting, pinching, hairpulling, arm-twisting, strangling, burning, stabbing, punching, pushing, slapping, beating, shoving, kicking, choking, biting, force-feeding, or any other rough treatment; Assault with a weapon or other object; Threats with a weapon or object; Deliberate exposure to severe weather or inappropriate room temperatures; murder.

Medication abuse: Inappropriate use of medication, including: withholding medication; complying with prescription instructions; over or under-medication.

Restraints abuse: forcible confinement; excessive, unwarranted or unnecessary use of physical restraints; forcing a person to remain in bed; unwarranted use of medication to control a person (also called "chemical restraint"); tying the person to a bed or chair.

\section{2. Sexual Violence}

Sexual violence occurs when a person is forced to unwillingly take part in sexual activity. Sexual violence includes, but is not limited to: touching in a sexual manner without consent (i.e., kissing, grabbing, fondling); forced sexual intercourse; forcing a person to perform sexual acts that may be degrading or painful; beating sexual parts of the body; forcing a person to view pornographic material; forcing participation in pornographic filming; using a weapon to 
force compliance; exhibitionism; making unwelcome sexual comments or jokes; leering behavior; withholding sexual affection; denial of a person's sexuality or privacy (watching); denial of sexual information and education; humiliating, criticizing or trying to control a person's sexuality; forced prostitution; unfounded allegations of promiscuity and/or infidelity; purposefully exposing the person to HIV-AIDS or other sexually transmitted infections.

\section{3. Emotional Violence}

Emotional violence occurs when someone says or does something to make a person feel stupid or worthless. Emotional violence includes, but is not limited to: name calling; blaming all relationship problems on the person; using silent treatment; not allowing the person to have contact with family and friends; destroying possessions; jealousy; humiliating or making fun of the person; intimidating the person; causing fear to gain control; threatening to hurt oneself if the person does not cooperate; threatening to abandon the person; threatening to have the person deported (if they are an immigrant).

\section{4. Psychological Violence}

Psychological violence occurs when someone uses threats and causes fear in an individual to gain control. Psychological violence includes, but is not limited to: threatening to harm the person or her or his family if she or he leaves; threatening to harm oneself; threats of violence; threats of abandonment; stalking / criminal harassment; destruction of personal property; verbal aggression; socially isolating the person; not allowing access to a telephone; not allowing a competent person to make decisions; inappropriately controlling the person's activities; treating a person like a child or a servant; withholding companionship or affection; use of undue pressure to: sign legal documents; not seek legal assistance or advice; move out of the home; make or change a legal will or beneficiary; make or change an advance health care directive; give money or other possessions to relatives or other caregivers; do things the person doesn't want to do.

\section{5. Spiritual Violence}

Spiritual (or religious) violence occurs when someone uses an individual's spiritual beliefs to manipulate, dominate or control that person. Spiritual violence includes, but is not limited to: not allowing the person to follow her or his preferred spiritual or religious tradition; forcing a spiritual or religious path or practice on another person; minimizing or making fun of a person's spiritual or religious tradition, beliefs or practices; using one's spiritual or religious position, rituals or practices to manipulate, dominate or control a person.

\section{6. Cultural Violence}

Cultural violence occurs when an individual is harmed as a result of practices that are part of her or his culture, religion or tradition. Cultural violence includes, but is not limited to: committing "honor" or other crimes against women in some parts of the world, where women especially may be physically harmed, shunned, maimed or killed for: falling in love with the "wrong" person; seeking divorce; infidelity; committing adultery; being raped; practicing witchcraft; being older. Cultural violence may take place in some of the following ways: lynching or stoning; banishment; abandonment of an older person at hospital by family; female circumcision; rape-marriage; sexual slavery; murder. 


\section{7. Verbal Abuse}

Verbal abuse occurs when someone uses language, whether spoken or written, to cause harm to an individual. Verbal abuse includes, but is not limited to: Recalling a person's past mistakes; expressing negative expectations; expressing distrust; threatening violence against a person or her or his family members; yelling; lying; name-calling; insulting, swearing; withholding important information; unreasonably ordering around; talking unkindly about death to a person; telling a person she or he is worthless or nothing but trouble.

\section{8. Financial Abuse}

Financial abuse occurs when someone controls an individual's financial resources without the person's consent or misuses those resources. Financial abuse includes, but is not limited to: not allowing the person to participate in educational programs; forcing the person to work outside the home; refusing to let the person work outside the home or attend school; controlling the person's choice of occupation; illegally or improperly using a person's money, assets or property; acts of fraud; pulling off a scam against a person; taking funds from the person without permission for one's own use; misusing funds through lies, trickery, controlling or withholding money; not allowing access to bank accounts, savings, or other income; giving an allowance and then requiring justification for all money spent; persuading the person to buy a product or give away money; selling the house, furnishings or other possessions without permission; forging a signature on pension cheques or legal documents; misusing a power of attorney, an enduring power of attorney or legal guardianship; not paying bills; opening mail without permission; living in a person's home without paying fairly for expenses; destroying personal property.

\section{9. Neglect}

Neglect occurs when someone has the responsibility to provide care or assistance for an individual but does not. Neglect includes, but is not limited to, the following: failing to meet the needs of a person who is unable to meet those needs alone; abandonment in a public setting; not remaining with a person who needs help.

Physical neglect: Disregarding necessities of daily living, including failing to provide adequate or necessary: nutrition or fluids; shelter; clean clothes and linens; social companionship; failing to turn a bed-ridden person frequently to prevent stiffness and bedsores.

Medical neglect: ignoring special dietary requirements; not providing needed medications; not calling a physician; not reporting or taking action on a medical condition, injury or problem; not being aware of the possible negative effects of medications.

Johan Galtung (1990) introduced in his article "Violence, Peace, and Peace Research" the term "structural violence". This type of violence refers to social structure or social institution that can harm people by preventing them from meeting of their needs. Galtung asserts that structural violence is an "avoidable impairment of fundamental human needs". As it is avoidable, structural violence is a high cause of premature death and unnecessary disability. Structural violence affects people differently in various social structures, it is very closely linked to social injustice. In above classification are presented some of these allusions. 


\section{TRIANGLE OF VIOLENCE}

"Cultural violence means those aspects of culture, the symbolic sphere of our existence exemplified by religion and ideology, language and art, empirical science and formal science (logic, mathematics) that can be used to justify or legitimize direct or structural violence. Cultural violence makes direct and structural violence look even feel right or at least not wrong" asserts Johan Galtung (1990). As in political science where are two important issues: the use of power and the legitimation of the use of power, also, violence studies are about two issues: the use of violence and the legitimation of that use. The psychological mechanism would be internalization. Through the cultural violence is emphasized the way in which the act of direct violence and the fact of structural violence are legitimized and thus rendered acceptable in society. "One way cultural violence works is by changing the moral color of an act from red/wrong to green/right or at least to yellow/acceptable; an example being "murder on behalf of the country as right, on behalf of oneself wrong". Another way is by making reality opaque, so that we do not see the violent act or fact, or at least not as violent. Obviously this is more easily done with some forms of violence than with others; an example being abortus provocufirs" shows Galtung.

Analyzing the human violence needs, more generally to life, there are four classes of basic needs: survival needs (negation: death. mortality); well-being needs (negation: misery, morbidity); identity, merrning needs (negation: alienation); and ,freedom needs (negation: repression) (Galtung,1980).

Violence is defined by the types described above, as direct violence, structural violence and cultural violence as super-type of violence put in each corner of a triangle (vicious), violence triangle as an image. When the triangle is stood on its 'direct' and 'structural violence' feet, the image invoked is cultural violence as the legitimizer of both. If the triangle is standing on its "direct violence" the head yields the image of structural and cultural sources of direct violence.

Direct violence is an event; structural violence is a process with ups and downs; cultural violence is an invariant, a "permanence" (Galtung, 1980), remaining essentially the same for long periods, given the slow transformations of basic culture.

\section{PREVENTION}

Poverty, lack of education, economic inequalities, economic subordination of states, economic underdevelopment, the aggressiveness of the media industry, propensity for violence, alcoholism are just some of the reasons that would be eliminated. Changing the underlying conditions that contribute to violence-in homes, schools, and neighborhoods prevents violence from occurring in the first place. Shifting the paradigm away from a singleprogram focus to a broader national, state, and city strategy, engaging leaders from multiple sectors and cultivates a systems approach to developing effective prevention initiatives that precede the need for criminal justice intervention.

To prevent violence, we must, first, stop perpetrating violence on children. This means no spanking or hitting. We also need to protect children from violent scenes on television or videos. We must change the messages about violence that we give to boys, and expect the same standards of nonviolent behavior from boys that we expect from girls. Furthermore, both boys and girls must be allowed to cry and rage. Otherwise, they harbor unresolved anger, resentments, frustrations, and fears that they may act out as violence toward others or 
themselves. Crying can be very effective in dissipating aggressive energy. Much of the emotional pain of childhood is an inevitable part of growing and learning. Children get hurt and experience stress even with the most caring parents and teachers. It is therefore vitally important to allow the natural healing mechanisms of crying and raging. It is important that people identify with one another and develop relationships with one another that are not just lustful. This is the essence and the personal source of the commandment, love one's neighbor as oneself.

\section{VIOLENCVE AND COMMUNICATION}

The media discourse has two vulnerabilities when is persuading. "The speech is subject to persuasion on its both constituents: language and reasoning. First of all, language has semantic ambiguities, morphological twisting and syntactic splits which are used in order to mislead the audience" shows Ştefan Vlăduţescu (Vlăduţescu, 2014). Secondly, reasoning (or ideology) has emphasized which allow sophisms, fallacies and natural arguments to interpose. The journalism is more vulnerable as more insinuation gateways for persuasion are offered in speech tools. The persuasive journalism is noxious, and noxious journalism is negative. By its harmfulness, by overbidding its own speech, journalism its own speech, journalism "may become a threat even to the structural constituents of the democratic order" (Vlăduţescu, 2014), a structural violence. In crisis and austerity times, the negative journalism affects the social system constituents. The system may collapse if the democratic structures are not fortified and if they do not have enough experience or the ability to face the destructive pressures. Negativism, as harmfulness, may be a source of disarray, of instability and of social anarchy. The main resort of the negativism is the financial concern, which inducts the journalistic means of the persuasion and pulls up its energies.

Reflection becomes reflex and reasoning becomes aberration because of the affluence of negative messages. Negativity makes the individual to feel confusion, derived from the indecision of his opinions, beliefs, attitudes and values. The negative journalism reveals them through persuasion deliberately. Processed in a misleading, whispering, intoxicating way, deeds, real, true facts, opinions and values are cunningly modified. Negative journalism seems to marginalize authenticity: the means and methods are the same, but reality distorted or its noxious parts are excessively emphasized. The audience cannot reject the form of address, but they can observe the journalistic communication articulacy. Except persuasion vulnerabilities, the audience is also unable to react to resurrection persuasion procedures (Vlăduţescu, 2014). Basically, in austerity times, negative journalism works hand in glove with two operations: confusing the audience, its attitude and behavior and exciting it, by a financial concern leading to least one of violence types, structural, cultural or direct violence.

There are four general victims: the society, the man in public, the responsible citizen, the informed man (Vlăduţescu, 2006). People are becoming increasingly concerned about the problems of violence at all levels of society. They are concerned about issues ranging from child abuse and family violence; to injustice, discrimination, inequality and the treatment of asylum seekers; to concerns about terrorism, weapons of mass destruction and war. Never before has there been such potential for violence, yet such prospects for peace and justice. Improving people's daily living conditions, and contributing to the creation of a peaceful and just world depends on our ability to understand the issues, recognize and manage our feelings, confront our prejudices, and develop new and creative solutions (Mingolarra, Arocena, Sabaris, 
2012). Communication is important in helping us address issues for a number of reasons. Some of action to this direction can be:

- By talking to each other we can recognise and acknowledge the very real, appropriate and adaptive concerns that we have about violence and injustice. Only when these concerns become a daily reality in our minds will we be motivated to take action.

- Our usual and understandable reaction to horrific ideas is to avoid them, although we cannot afford to react in this way. Communicating about our fears can enable us to understand how and why we have avoided facing them, and how we can change this response.

- Communication can also serve as an important action against direct and indirect violence. If we can find others who share our views, we can exert considerable influence through a collective effort and ensure that our representatives understand how important the issue is to us. There are many examples of the weight of public opinion directly influencing government policies (e.g. moratorium marches leading to the end of the Vietnam War; forest protests leading to a reversal in the decision to dam the Franklin River). At other times, action may have brought the government intervention (e.g. granting visas to certain asylum seekers through special dispensation), or at least put the government on notice and raised the issue as one of great importance (e.g. sorry marches, peace rallies protesting a non-UN sanctioned war in Iraq). Even individual letters from members of the community to their government representative can bring a response, government intervention, a question being raised in the House, or even aninternal inquiry into the matter. Non-Governamental Organisations have also an important role in this direction.

- Communicating with others is an important way to gain support and keep your motivation and enthusiasm alive. It also prevents from becoming disillusioned, burnt out, overwhelmed, or succumbing to feelings of helplessness and hopelessness.

- Maintaining discussions at any level is important in recognising shared humanity. It is not always easy to start conversations on difficult topics maintaining an assertive tone. This tip sheet offers suggestions about how to talk to a range of people about these challenging and controversial subjects.

\section{CONCLUSIONS}

Violence can start at any corner in the direct, structural, cultural violence triangle and is easily transmitted to the other corners. With the violent structure institutionalized and the violent culture internalized, direct violence also tends to become institutionalized, repetitive, ritualistic, like a vendetta. This triangular syndrome of violence should then be contrasted in the mind with a triangular syndrome of peace in which cultural peace engenders structural peace, with symbiotic, equitable relations among diverse partners, and direct peace with acts of cooperation, friendliness and love. It could be a virtuous rather than vicious triangle, also self-reinforcing. This virtuous triangle that we expect would be obtained by working on all of three corners at the same time, not assuming that basic change in one will automatically lead to changes in the other two. 


\section{ACKNOWLEDGMENT}

This work was partially supported by the grant number $33 \mathrm{C} / 2014$, awarded in the internal grant competition of the University of Craiova.

\section{References}

[1] Johan Galtung (1980). Peace and World Structure. Essays in Peace Research. Vol. IV. Copenhagen: Ejlers.

[2] Johan Galtung, Journal of Peace Research 27(3) (1990).

[3] Andrzej Borowski, International Letters of Social and Humanistic Sciences 14 (2014) 7-17.

[4] Jose Antonio Mingolarra, Carmen Arocena, Rosa Martín Sabaris (2012). Violence and Communication. University of Nevada, Reno. C2

[5] Freud Sigmund (1915). Thoughts on War and Death. London.

[6] Sigmund Freud (1930). Civilization and its Discontents. London.

[7] Krug et al., "World report on violence and health", World Health Organization, 2002.

[8] Andrzej Borowski, International Letters of Social and Humanistic Sciences 14 (2014) $33-41$.

[9] Florentin Smarandache, Ştefan Vlăduţescu (2014). Communication Neutrosophic Routes. Columbus, OH: Educational Publishing.

[10] Andrzej Borowski, International Letters of Social and Humanistic Sciences 4 (2013) $70-74$.

[11] Ioan Constantin Dima, Ştefan Vlăduţescu (2012). Persuasion elements used in logistical negotiation: Persuasive logistical negotiation. Saarbrucken: LAP Lambert Academic Publishing.

[12] Alina Tenescu, Mirela Teodorescu, Communications in Applied Sciences 2(1) (2014).

[13] Ştefan Vlăduţescu (2013). What Kind of Communication Is Philosophy. Jokull.

[14] Daniela Gîfu, Mirela Teodorescu, International Letters of Social and Humanistic Sciences 17 (2014) 119-127.

[15] Andrezj Borowski, International Letters of Social and Humanistic Sciences 2 (2014) 110-121.

[16] Florentin Smarandache, Ştefan Vlăduţescu (2014). Neutrosophic Emergences and Incidences. Saarbrucken: LAP Lambert Academic Publishing.

[17] Ioan Constantin Dima, Mirela Teodorescu, Daniela Gifu, International Letters of Social and Humanistic Sciences 20 (2014) 46-55

[18] Tomáš Hes, Anna Poledňáková, International Letters of Social and Humanistic Sciences 2 (2013) 18-31. 
[19] Ştefan Vlăduţescu (2013). A battle with uncertainty 1 of the communication as an academic discipline: title uncertainty. Studies on Literature, Discourse and Multicultural Dialogue, 493-504.

[20] Donovan A. McFarlane, International Letters of Social and Humanistic Sciences 4 (2013) 35-44.

[21] Andrezj Borowski, International Letters of Social and Humanistic Sciences 3 (2013) 69-74.

[22] Ş. Vlăduţescu, E. M. Ciupercă (2013). Next Flood Level of Communication: Social Networks. Aachen: Shaker Verlag.

[23] Daniela Gîfu, Mirela Teodorescu, International Letters of Social and Humanistic Sciences 18 (2014) 34-38.

[24] A. Borowski, International Letters of Social and Humanistic Sciences 11 (2014) 1-168.

[25] Ștefan Vlăduțescu (2013). Principle of the Irrepressible Emergence of the Message. Jokull.

[26] Andrzej Borowski, International Letters of Social and Humanistic Sciences 3 (2013) 46-53.

[27] Ștefan Vlăduțescu, International Letters of Social and Humanistic Sciences 10 (2014) 100-106.

[28] Kinga Dziwańska, International Letters of Social and Humanistic Sciences 7 (2013) 96-112.

[29] Ștefan Vlăduțescu, International Letters of Social and Humanistic Sciences 7 (2014) 8-13.

[30] Colhon M. (2013). Automatic Lexical Alignment between Syntactically Weak Related Languages. Application for English and Romanian. In Computational Collective Intelligence. Technologies and Applications (pp. 266-275). Springer Berlin Heidelberg.

[31] Janusz Grabara, Michal Kolcun, Sebastian Kot, International Journal of Education and Research 2(2) (2014).

[32] Ştefan Vlăduţescu, Journal of Studies in Social Sciences 5(2) (2013).

[33] Marian Siminică, Aurelia Traistaru, International Journal of Education and Research 1(12) (2013).

[34] Stefan Vladutescu, Analele Universităţii din Craiova. Seria Ştiinţe Filologice. Lingvistică (1-2) (2013) 355-363.

[35] Max G. Craig, Journal of Studies in Social Sciences 8(1) (2014).

[36] Jason L. Powell, International Letters of Social and Humanistic Sciences 7 (2014) 22-30.

[37] Aurelia Traistaru, Marioara Avram, International Letters of Social and Humanistic Sciences 13 (2014) 79-88.

[38] Ştefan Vlăduțescu, Communications in Applied Sciences 2(2) (2014).

[39] Agnieszka Ulfik, Stefan Nowak, Polish Journal of Environmental Studies 23(3) (2014). 
[40] J. Tabor, Place of Non-formal Education in the Career Building Process. Polish Journal of Management Studies.

[41] Ioana-Rucsandra Dascălu (2014). Etude sur les passions dans la culture ancienne et moderne. Craiova: Editura Universitaria.

[42] V. A. Enăchescu, C. Damasaru, Revista de Management Comparat Internaţional/ Review of International Comparative Management 14(4) (2013) 644-653.

[43] Cristina Anca Păiuşescu, Oana Duţă, Dreptul comunicării. Consideraţii teoretice şi legislaţie relevantă. "Editura Universitară” Publishing House, Bucharest, 2011.

[44] J. Bushati, A. Tana, G. Dibra, E. Lezha, European Scientific Journal 10(13) (2014).

[45] B. Slusarczyk, A. Broniszewska, Entrepreneurship of Women in Poland and the EuQuantitative Analysis. Polish Journal of Management Studies.

[46] Vlad Roşca, Theoretical and Applied Economics 1(1) (2012) 127.

[47] Sebastian Kot, Beata Ślusarczyk, The Journal of American Business Review Cambridge (2014).

[48] Ștefan Vlăduțescu, International Letters of Social and Humanistic Sciences 24 (2014) 86-94.

[49] R. Y. Papancheva, K. A. Dimitrova, K. N. Manev (2010). Teaching IT in the Primary School-Some Aspects of Propaedeutics of Informatics Knowledge. InCSEDU (2) (pp. 185-188).

[50] Anda Rădulescu (2008). Bref aperçu des grands courants en traduction: théories européennes et américaines. Craiova: Editura Universitaria.

[51] Tomáš Hes, Alena Neradová, Karel Srnec, International Letters of Social and Humanistic Sciences 7 (2013) 55-75.

[52] Ştefan Vlăduţescu, International Letters of Social and Humanistic Sciences 25 (2014) $16-24$.

[53] I. Stavre (2011). Comunicare audiovizală: aspecte ale europenizării societăţii româneşti. Tritonic.

[54] M. Drămnescu (2014). Argumentation for social instruction model from the perspective of social innovation. eLearning \& Software for Education.

[55] Andrzej Borowski International Letters of Social and Humanistic Sciences 7 (2013) $113-118$

[56] Andrzej Borowski, International Letters of Social and Humanistic Sciences 11 (2013) 100-105

[57] Okezie A. Ihugba, Alex Odii, A. C. Njoku, International Letters of Social and Humanistic Sciences 5 (2014) 21-34

[58] Ştefan Vlăduţescu, European Scientific Journal 9(32) (2013).

[59] Camelia. Manolescu. (1997). Le trust en droit anglais. (Doctoral dissertation).

[60] G. Rajović, J. Bulatović, International Letters of Natural Sciences 1 (2014) 33-53. 
[61] Ştefan Vlăduțescu (2006). Comunicare jurnalistică negativă. București: Editura 61 Academiei.

[62] Aurika Komsaare, International Journal of Learning 16(6) (2009).

[63] J. H. Gasderell, International Letters of Social and Humanistic Science 22 (2014) 85-91.

[64] Vladimir Modrak, Mirela Teodorescu, Daniela Gîfu, International Letters of Social and Humanistic Sciences 24 (2014) 56-65.

[65] Jason L. Powell, International Letters of Social and Humanistic Sciences 16(2) (2014) 132-143.

[66] Jason L. Powell, International Letters of Social and Humanistic Sciences 17(1) (2014) $1-60$. 